\title{
Discussion on Culture Introduction In Japanese Language Learning
}

\author{
Yemeng Li \\ School of Foreign Languages \\ Linyi University \\ Linyi, China \\ e-mail: liyemeng@lyu.edu.cn
}

\begin{abstract}
Language and culture are closely interweaved. Thereby, it is a must to know the culture that a language loads when learning a foreign language. The paper points out that Japanese teaching is not merely to impart students to language point out also to cultivate their cultural awareness. Only in this way students can communicate well with the language they have learned. This paper concentrates on the necessity of foreign culture introduction in Japanese teaching and elaborates on the contents and detailed methods of culture introduction.
\end{abstract}

Keywords—Japanese Language Teaching; culture introduction

\section{INTRODUCTION}

Different nations possess different cultures. Language is the carrier of culture, whereas the former has an effect on the latter. Culture includes all the products shared by all the human society and all the forms of one nation's activities. Language is one important part of culture, and plays an important role in cultural development. On one hand, language is the basis of culture, there will not be culture without language. On the other hand, culture influences language while language reflects culture, and no language can exist without its culture. Language and culture have mutual connection and mutual influence. The ultimate aim of learning a language is to make cross-cultural communication. Without understanding of its culture and the differences between it and home culture, there will not be the slightest chance of success in the cross-cultural communication.

The so-called culture introduction means that we should introduce the cultural background and content of its language in the language teaching, integrating language learning into the social culture and achieving the best target in foreign language teaching. Thus, we have to introduce related Japanese culture in daily Japanese teaching with the aim of cultivating and improving students language ability, which will ensure that the students make cross-cultural communication in a smooth way. However, in the practice of Chinese universities, the culture introduction is not considered as an important tool and role. Many instructors pay little attention to teach more details about the culture, history, literary, celebrities, current science and technology and the newest changes in the target-language society. This should be corrected immediately. We not only learn how to speak a foreign language, we but also have to know what the foreigners are thinking and how they think of us Chinese. And this task is closely related to the aim of cultivating more and more qualified applied and compound talents, ready for our foreign polices and modern construction.

\section{THE NECESSITY OF CULTURE INTRODUCTION IN JAPANESE TEACHING}

Over a long - enough period, the traditional language skill teaching and learning has been influencing domestic Japanese teaching. The traditional language skill teaching fragments language and culture completely, putting more emphasis on learning grammar and training skills, while ignoring focus on cultural differences. Thus, this results in lack of consciousness of cross-cultural communication. And the students usually bring Chinese cultural habits into the process of learning Japanese, making mistakes in selecting words. That is to say, the communication turns out to be unsuccessful because of not learning about the communication culture of the other party, and then the expected aim will fail in the end.

With the development of the age, the scale of Japanese teaching in China shows the trend that expands ceaselessly, meanwhile the aim of Japanese teaching is changing continually. In the past, we mainly train the students' ability to listen, speak, read, write and translate. However, the talents' ability of communicating is gaining more attention, with the fact that the society tends to require more from the language professionals.

Besides, many people have come into an established mode of thinking, holding the view that Chinese and Japanese are of one origin, which is proved to be only one-sided. From the historical view of point, Japan got much cultural nourishment from China, showing many factors similar to Chinese oriental characteristics. After all, China and Japan are different from each other in historical background, natural environment and human environment, and on the other hand, Japanese culture is a product of a long historical process, where Japanese people absorbed foreign cultural influences, Chinese culture included, and transplanted them to national Japanese spirit. Therefore, we will not acknowledge and use Japanese in the right way without knowing about the features and changes of Japanese culture. 
Take the greeting as an example which is bound up with people's daily life. Greetings involve with what people are concerned about most and with what is general around, and different countries and regions usually denote cultural characteristics specifically. Among Chinese acquaintances, the greeting was common that " Have you had your dinner?", which dates back to the mental existence in an old saying "Food is the first necessity of the people", embodying people's concern on defensive living. For Chinese, this is a common and casual greeting, whereas foreigners are confused totally, for the latter don't figure out that that's only one kind of greeting among Chinese. Japanese greet others by talking about the weather, while Chinese are not used to doing so. Although Chinese can have a discussion on the weather, the discussion is not a greeting in the beginning.

Another demonstration is that Chinese and Japanese differ a lot in using analogy. China is a country with vast land resources, so when describing a person who is generous or spends lavishly, we can use the word "spend money like soil” 。In Japan, on the contrary, it will be described as “お 金を湯水のように使う”， because for Japan with confined spaces and many volcanoes, spring resources are richer than land and soil.

Consequently, it's not far from being desired if the instructors only teach the students a series of rigid grammar rules and adequate vocabulary, in that the ultimate aim of Japanese learning is to train students' ability to make crosscultural communication. Thus, we should not only let students master the skills of listening, speaking, reading and writing, but also train their social cultural ability, which enjoys more importance. And the chief and effective method is to introduce Japanese culture into Japanese teaching. While instructing the meaning of language vocabulary and grammar combination, instructors take the form of analyzing the construction of language and meaning to discover what kind of culture is hidden inside, so that the learners can understand the cultural background and to some extent, the understanding can be transformed into communication ability. By doing this, the cultural atmosphere can be created, making the learners feel close to Japanese culture, which can motivate them to learn Japanese spontaneously and actively, so that their crosscultural communication can be improved.

\section{THE CONTENT OF CULTURE INTRODUCTION IN JAPANESE TEACHING}

First, confirm that you have the correct template for your paper size. This template has been tailored for output on the US-letter paper size. If you are using A4-sized paper, please close this template and download the file for A4 paper format called "CPS_A4_format".

\section{A. Words culture}

This term means the range, feeling and suggestive meaning of words, including some phrases, proverbs, and idioms with cultural background. Word is an accretion of culture, which presents the cultural features most directly and rapidly. During the teaching process, the instructors should explain on-reading, kun-reading and other phonologic rules of Japanese words, and on the other hand, they need to pay more attention to the cultural significance behind every single word. Through this, we can increase students' learning interest and then strengthen the effect of memorizing words.

There are many Japanese kanji similar to Chinese characters, with different meanings instead, such as 「手紙」 （书信）、「大丈夫」（没关系）、「怪我」（受伤）、

「娘」（女儿） and so on. This fact reminds us to be aware that never interpret a Japanese word without real understanding while learning.

In the real communication, some words are commonly used and in accordance with the grammar. Without Japanese cultural knowledge, these words will cause misunderstanding or even contradiction. For example, in Japanese, “あなた” is translated into "you" in Chinese, whereas in Japan, this word is mostly use between lovers and couples. Many beginners use it regardless of different targets, making them embarrassed.

\section{B. Discourse culture}

Speech event of any individual is restrained within a certain mode of human thinking with some cultural traditions. Speech is influenced and circumscribed by culture in three aspects:

1) The choice of topic. Japanese avoid talking about age, income and so on. As an island country, Japan undergoes complex climate change. And Japanese attach much weight to the harmony and unity of human and environment, so there are many greetings about weather, season.「天気がいいです ね」「暑いですね」。 Meanwhile, exchanging the usual pleasantries about the weather has been always a set mode in letters.

2) The choice of code. That's to say, people discuss one topic in what kind of way and style. For example, when refusing an invitation, Chinese tend to say "No, I can't", replying directly like this. But more Japanese reject in a gentle and indirect way, trying to avoid direct refusal like “いい え” , or just tell the truth with no interest relationship between both parties. Therefore, we often hear「ちよつと用事がある ので」「都合が悪いので」 or some reasons of being sick like「ちよつと体調が悪いので」, which reflects completely that Japan is a nation where harmony acts as fundamentality and harmonious interpersonal relationship is of vital importance.

Japan is a country attaching much weight to status and class, and Japanese employ different form of language expression according to internal - external, near-far, and high-low relation, so the Japanese honorific, to the greatest extent, shows the phenomenon of both language and culture with Japanese characteristics. The Japanese honorific is a kind of language expression to show the speaker's respect, in the communicating activity, according to the role of the speaker and the listener, and other elements like the pecking order, old and young age, and near-far relationship. The Japanese honorific stands high in Japanese, and demonstrates Japanese way of thinking, thoughts and emotions, and art of communication. Knowing how to use the Japanese honorific is considered what Japanese should have, 
and an important fundamental method in social communication. Naturally, for us, being "foreigners", is a difficult point, too.

3 ) Organization of speech. The grammar and mode of speech act. Japanese prefers to be thought of than expressed, emphasizing the context. Therefore, its language is in a form with loose and malleable structure. The learners should understand the language in combination with the context there and that time, and the information well known to each other.

Take「結構です」 as an example, it can mean “Ok” orally, and can refer to "No, thanks". At this time, we can only predict each other's intensions based on the surrounding and tone. Compare the two dialogues as follows.

Dialogue one：「山下：お茶をもう一杯、いかがです か。」 (Another cup of tea?)

「小野：いえ、もう結構です。十分いただきました から。」 (No, thanks. I'm already full.)

Dialogue two：「レストランの店員：ランチのコーヒ 一は、食後にお持ちしてよろしいですか。」（The coffee, delivered after dinner? )

\section{「李秀麗 : はい、それで結構です。」（Yeah, fine.）}

If we know the speeches are different because of cultural differences, it will do good in helping students use the right pattern of Japanese more quickly in practical.

\section{Non-verbal culture}

Communication falls into verbal and non verbal, the two forms. As one of important contents in cultural introduction, non-verbal culture includes dressing, expression, gesture, figure, manner, look etc. One research result proves that most of information exchange is not accomplished verbally in faceto-face communication.

The obvious example is "bowing and scraping" of Japanese, which is considered as behavior of flattery, whereas in Japan as basic social manners. Bowing is one simple act, but the angle of bowing is quite sartorial, which is related to each other's age, position, gender, and level of respect. Besides, when listening to others or answering the phone, Japanese will bow frequently. All above embody the Japanese characters of being modest, prudent and polite.

\section{THE METHODS OF CULTURAL INTRODUCTION IN JAPANESE TEACHING}

\section{A. Commenting}

Commenting is a usual and basic teaching method employed by instructors. During the teaching process in class, however, the teacher should not be constrained to the textbook, work out his or her own teaching program combined with Japanese cultural background instead, making the cultural content and language staff together.

For example, when referring to「桜」, the instructor can give students a brief introduction of the type and florescence of cherry, and why Japanese love cherry. So that students can feel the inside meaning in「花は桜、人は武士」, related to group consciousness, sense of beauty and the samurai moral belonging to Japanese national flavor.

\section{B. Comparing}

Learning a foreign language is a process comparing native language with target language. And the rule of comparison should be throughout the whole process. This demands that the instructor should be armed with Japanese language ability and culture, what's more, he or she should have Chinese cultural literacy, enabling to teach with effortless work.

Through comparison, we can make research on the similarities and differences between Japanese and Chinese cultures, and we can know all the differences of Japanese and Chinese changes in family, word order and modesty. Then we can establish the awareness of excluding the influence of mother language. Just as mentioned above, Japanese tend to refuse and reject in an indirect way, instead of expressing themselves directly.

\section{Intuitivism}

It's not enough to convey the cultural background of the target-language country only through explaining by instructors. The students should strengthen the study through more direct practice. They can create varies of language contexts through means of different channels, to absorb and experience foreign cultures and develop the practical use of cultural knowledge.

The instructor can gather some Japanese materials and pictures, making students know about foreign arts, history, and local customs and culture; show the students directly through Japanese movies, TV programs, slides, videos and other stuff; make students edified by the practical use of Japanese; recommend reading books, magazines whose topic is foreign culture; ask students to listen to news report on NHK, so that they can expose themselves to standard Japanese broadcast, so that they can be improved in listening and speaking because of the imitation and translation activity, and most important of all, they can be familiar with Japanese society and culture through news reports.

Try to encourage qualified students to communicate with those who are native Japanese speakers. Except direct contact, the internet should be made full use of. On one hand, students can learn Japanese in a relatively real target-language context; on the other hand, they can obtain the acknowledgement and comprehension of Japanese culture more deeply through practical communication.

Integrated with one chapter, give one lecture or a series of lectures regularly, acting with its own purpose. Or offer related elective courses. The cultural lectures can reshape and reconstruct piecemeal cultural information, providing students with latest research and training and improving students' dictation and observation. What's more, elective courses can increase student's awareness and interest in culture-related elements systematically. 


\section{Case study}

Case study is one classical teaching method in foreign language teaching, such as role play. It can fully motivate the students to learn by themselves actively, and can realize the Japanese knowledge, with the result of deepening understanding and using of Japanese culture.

In conclusion, during the Japanese teaching process, we must not look only at language learning, but pay attention to the differences between Chinese and Japanese cultures, and then get to know and study these differences. For most of the teachers of Japanese and foreign language education workers, they have to attach much more importance to culture in learning a language. Meanwhile, they should help students know Japanese social culture actively in various ways, to cultivate the students to be modern practical talents with strong integrated abilities, who know about Japanese conditions and have enough knowledge and cultivation about Japanese society, politics, economy and culture.

\section{REFERENCES}

[1] Hu Wenzhong, Introduction to Cross-Cultural Study, Foreign Language Teaching and Research Press, 1999

[2] Zhangqiang, Like, Discussion on Cculture Introduction in College Foreign Language Teaching (J). Chinese Adult Education, 2007(9). 